\title{
ASSESSMENT OF FACTORS AFFECTING THE AMOUNT OF IMMOVABLE PROPERTY TAX IN LATVIA
}

\author{
SAndra Stucere ${ }^{1}$, Gunita Mazure ${ }^{2}$ \\ Latvia University of Agriculture (Latvia)
}

\begin{abstract}
The research aim is to analyse the peculiarities for application of immovable property tax in Latvia and to assess the main factors affecting the amount of immovable property tax and contradicting the basic principles for imposing taxes. It is essential to review the methods how the State Land Service determines cadastral values for real estate, since the cadastral value is the base for calculation of immovable property tax. The revision is required as the establishment of a fair tax system is impossible without adequate and comparable cadastral values. In the future, land shall be valued pursuant to lease and not to expropriation transactions in Latvia, while the cadastral valuation of buildings might be done consistent with the method of expenses by determining construction expenses of buildings. The issue on mass inspection of physical condition of buildings and data updating shall be solved in Latvia. In addition, an issue on possibilities to apply the most fair procedure for tax calculation shall be solved on the governmental level, i.e. to calculate taxes consistent with procedure for the use of immovable property registered in the Land Register as well as to cancel the limitation for increase of immovable property tax stated by the municipality and to regulate the tax burden through tax rates.

KEY WORDS: immovable property tax, limitation for the tax increase, property structure, cadastral value.
\end{abstract}

\section{JEL CODES: H29}

\section{Introduction}

Tax administration efficiency is one of the key factors influencing successful development of the state economy, since the implementation of governmental functions greatly depends on the state tax policy and the amount of collected taxes. Regular and sufficient tax collection ensures financing of the governmental expenditure and economic development in the short- and long-term.

Issues on the role of immovable property tax and the alignment and development perspectives of immovable property tax sphere have been frequently discussed in Latvia within the past years. Much larger attention has been paid to the regulating function of taxes - to promote efficient use of immovable property to gain maximum benefit from the immovable property item for the entire society.

Research object is immovable property tax in Latvia.

Topicality of the research theme is based on the wish to study problems and to analyse the main factors affecting the amount of immovable property tax in Latvia as well as to provide solutions in the sphere of immovable tax development.

1 Sandra Stucere - Latvia University of Agriculture, Faculty of Economics, Mg. oec., PhD student; Riga City Council, Municipal Revenue Administration, Head of taxpayers service department. Scientific interests: municipal tax, regions economics.

E-mail: Sandra.Stucere@riga.lv

Tel.: +37129263924.

2 Gunita Mazūre - Latvia University of Agriculture, Faculty of Economics, Dr. oec., assoc. professor. Scientific interest: financial support, crediting, investments, rural development.

E-mail: Gunita.Mazure@1lu.lv

Tel.: +37129844628. 
The research is done based on the hypothesis that in Latvia, individual factors affecting the amount of immovable property tax contradict the basic principles for imposing taxes.

To verify the hypothesis, the following research aim is set: to analyse the peculiarities for application of immovable property tax and to assess the main factors affecting the amount of immovable property tax in Latvia.

The following tasks are advanced to achieve the set aim:

- to analyse the application of immovable property tax and tax revenues in Latvia;

- to study the main factors affecting the amount of immovable property tax in Latvia and to provide possible solutions in the sphere of immovable tax development.

The monographic descriptive method as well as the methods of economic analysis and statistical data analysis is applied to achieve the set research aim.

Legal and regulatory enactments of the Republic of Latvia and documents related with immovable property tax as well as data of the Ministry of Finance of the Republic of Latvia on tax revenues for the period of 2006-2011 are used for the research purposes to analyse the application of immovable property tax and tax revenues in Latvia.

Personal experience of one of the authors (S. Štucere) and data of the information system of Immovable Property Tax Administration of Riga City Council are used to analyse factors affecting the amount of immovable property tax.

\section{Application of immovable property tax in Latvia}

At present, the tax system of Latvia is not sufficiently directed towards ensuring a sustainable development of the state socio-economic development. The tax system of Latvia may be characterised as unstable as it is essentially changed on a relatively frequent basis. The tax system of Latvia is mainly directed towards employment taxes, i.e. taxes that are paid from work payment by employees and their employers and not towards consumption taxes or capital taxes. It is also shown by the breakdown of the general government consolidated tax revenues by types of taxes in 2011. According to the data of Figure 1, the majority or $52.9 \%$ of tax revenues are constituted of employment taxes, $27.2 \%$ - consumption taxes, $12.2 \%$ - resource taxes, and only $7.7 \%$ - capital taxes. Immovable property tax is included into the group of capital taxes and its share equals to $2.8 \%$ (Kopsavilkums par budžeta ieņēmumu daḷas izpildi, 2011).

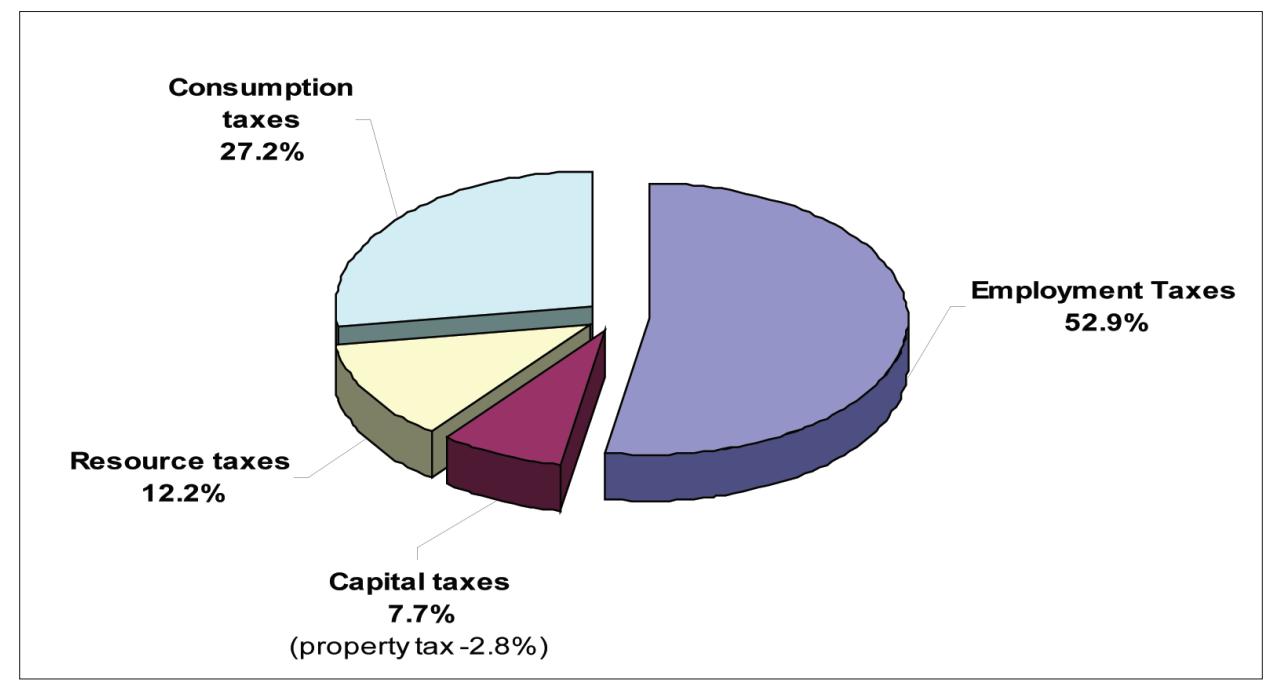

Figure 1. Breakdown of the general government consolidated budget tax revenues by types of taxes in 2011 Source: Kopsavilkums par budžeta ien̦ēmumu dạ̦as izpildi, 2011 
Immovable property tax is administered by municipalities and it is the only tax, which is paid to the municipal budget for $100 \%$. Immovable property tax, which is more neutral towards the general economic system compared with other taxes, is most directly related with the territorial management and socio-economic development of particular local government. Its items - land and buildings are localised, relatively stable, and explorable, thus, facilitating the tax administration.

Items taxable by immovable property tax and tax rates in Latvia are outlined in Table 1. In Latvia, the cadastral value serves as the basis for immovable property tax. Latvia has a large set of taxable objects and different tax rates. Land, buildings, and engineering constructions are levied at $1.5 \%$ of the property cadastral value, while a proportional rate within $0.2 \%-0.6 \%$ is imposed on residential buildings. Immovable property tax is imposed on unutilised agricultural areas and ruinous environment degrading constructions at a rate of $3 \%$ of the cadastral value (Likums Par nekustamā īpašuma nodokli, 2011).

Table 1. Application of immovable property tax in Latvia in 2012

\begin{tabular}{|l|l|l|}
\hline \multicolumn{1}{|c|}{ Tax base } & \multicolumn{1}{|c|}{ Taxable item } & \multicolumn{1}{c|}{ Tax rate } \\
\hline \multirow{5}{*}{ Cadastral value } & Land & $1.5 \%$ \\
& Buildings & $1.5 \%$ \\
& Engineering constructions & $1.5 \%$ \\
& Residential buildings & $0.2-0.6 \%$ \\
& Unutilised agricultural area* & $3 \%$ \\
& Ruinous environment degrading constructions $* *$ & $3 \%$ \\
\hline
\end{tabular}

* excluding land, the area of which does not exceed one hectare or which has restrictions for agricultural activities stated by regulatory enactments

** Binding Regulations issued by every municipality prescribe procedure for the calculation of immovable property tax

Source: Likums par nekustamā īpašuma nodokli, 2011

An essential novelty in the administration process of immovable property tax has been introduced in Latvia from 2012. Local governments have the rights to issue Binding Regulations, which prescribe the rights to apply the increase of tax rate limitation in 2012 or retain the amount of tax at the rate of 2011 as well as to state whether the immovable property tax is imposed on auxiliary buildings and environment degrading constructions (Likums par nekustamā īpašuma nodokli, 2011).

Immovable property tax has a significant share in municipal budgets, since it is the second largest tax in terms of revenues. The analysis of immovable property tax revenues (Figure 2) for the period of 2006-2011 shows that they have an increasing tendency. In 2011, immovable property tax revenues have increased by LVL 43.8 million or $66 \%$ compared with 2006.

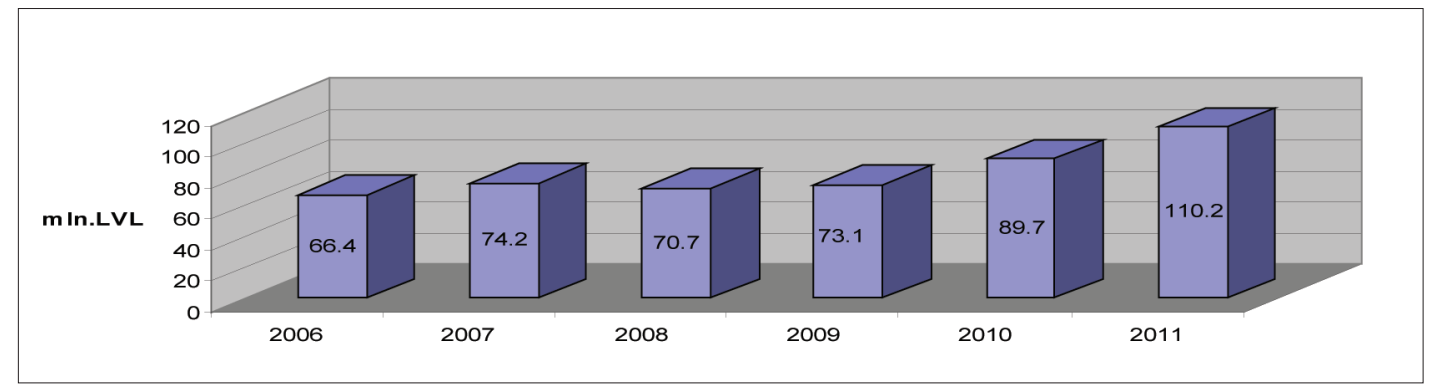

Figure 2. Immovable property tax revenues from 2006 to 2011, million LVL

Source: Par tautsaimniecības attīstību un kopbudžeta izpildes gaitu, 2007; Kopsavilkums par budžeta ieņēmumu daļas izpildi, 2010; Makroekonomikas un budžeta apskats, 2011 
The increase of immovable property tax base (cadastral value) as well as changes in tax rates and expansion of the set of items taxable by immovable property tax may explain the growth of immovable property tax revenues. The immovable property tax rate was raised from 2010 for land and non-residential buildings to $1.5 \%$ of the cadastral value (instead of a $1 \%$ rate set earlier). Taxation of engineering constructions ( $1.5 \%$ of the cadastral value) and residential buildings within the range of $0.1 \%-0.3 \%$ of the cadastral value was started at the same time. Immovable property tax rate for residential buildings was doubled to $0.2-0.6 \%$ from 2011. Hence, in 2011, these changes resulted in the largest immovable property tax revenues in Latvia amounting to LVL 110.2 million.

Lately, the possibility to increase exactly the immovable property tax rate is being emphasised in Latvia. The expansion of items taxable by the immovable property tax and increase of tax rates are based on simpler and easier administration of this tax compared with other taxes. The government of Latvia prefers those types of taxes, which reduce the possibility to avoid paying of taxes, thus, reducing the share of shadow economy.

The government of Latvia has envisaged supporting changes in the sphere of immovable property tax also in 2013. Therefore, the government will ensure greater participation of municipalities in the determination of tax rates (within the range of $0.2 \%-3 \%$ set by the central government), more precise compliance of tax burden with the property value and additional revenues (Likumprojekta "Grozījumi likumā Par nekustamā īpašuma nodokli”, 2012).

\section{Factors affecting the amount of immovable property tax in Latvia}

Contemporary economic literature earmarks the following basic principles of tax policy:

1) economic efficiency - tax system shall not distort efficient distribution of resources in the national economy;

2) simple administration - tax system shall be as much as possible easy and cheap to administer. It is required to assess the procedure and mechanism of administration by evaluating the necessary expenses for tax collection;

3) flexibility - tax system shall react fast on the changes of economic conditions. Tax system shall be established so that tax revenues increase simultaneously with the improvement of economic development without increasing tax rates, tax base or changing other conditions in tax legislation;

4) uniformity and justice - tax system shall be properly related to different taxpayers. It shall be fair and equally cover all the taxpayers (Ketners, Titova, 2009: 34).

Based on the key principles of tax imposition, the research studies and analyses the main factors affecting the amount of immovable property tax in Latvia, and provides solutions in the sphere of immovable property tax development.

2.1. Impact of the limitation for increase of immovable property tax on the tax amount

In Latvia, the law "On Immovable Property Tax" prescribes the norm that the amount of immovable property tax is limited from 2008 upon the condition that after updating of the cadastral value of immovable property tax, the amount of immovable property tax shall not exceed the amount of tax calculated for the previous taxation year (not taking into account the abatements) by more than $25 \%$ for each unit of land and each building separately (condition that the purpose for use of the immovable property does not change was in force till 2011) (Likuma "Par nekustamā īpašuma nodokli" normu piemērošanas kārtība", 2011).

At present, this principle contradicts the following principle of tax imposition - uniformity and justice. At the end of 2007, the mentioned condition was stipulated for the situation when cadastral values of immovable property sharply increased in 2008 and considerable changes were not envisaged in the real estate 
market. However, the situation has changed from 2010 - activity of the real estate market and prices has fallen dramatically, thus, essentially affecting cadastral values of properties (Fridriksone, 2009: 5).

To provide an insight in the changes of cadastral values and specificity for calculation of immovable property tax, the authors will analyse (Table 2) a sample for the calculation of immovable property tax for the land area behoving to the shop building on Gobas iela 14 in Riga for the period of 2007-2012. The data of Table 2 show that in 2008 (cadastral value - LVL 67646) the cadastral value has increased by LVL 57698 or almost six times compared with 2007 (cadastral value - LVL 9948). A considerable growth in the amount of immovable property tax (in 2008 - LVL 676.46) was also forecasted due to these changes. However, applying limitation for the tax increase the amount of immovable property tax grew by $25 \%$ compared with 2007 and equalled to LVL 186.53. In 2009, it grew by $25 \%$ compared with 2008 and comprised LVL 233.16. Therefore, in 2008 and 2009, limitation for the tax increase adopted by the government of Latvia substantially protected taxpayers from the fast increase of immovable property tax. On the contrary, the cadastral value had an annual tendency to decrease for the period of 2010-2012, while the amount of tax continued to increase annually by $25 \%$ compared with the previous year and comprised LVL 455.39 in 2012. However, the amount of tax would be LVL 746.10, if the tax were calculated according to the cadastral value (without applying the limitation for the tax increase).

Table 2. The calculation of immovable property tax applying limitation for the increase in 2007-2012

\begin{tabular}{|c|c|c|c|}
\hline \multirow[b]{2}{*}{ Year } & \multicolumn{3}{|c|}{ Shop building (Gobas iela 14, Riga) behoving land area 2487 m² $^{2}$} \\
\hline & $\begin{array}{l}\text { Calculation of immovable property tax } \\
\text { by the cadastral value }\end{array}$ & $\begin{array}{l}\text { Calculation of immovable property tax } \\
\text { applying limitation for the tax increase }\end{array}$ & Real tax rate \\
\hline 2007 & $\begin{array}{l}\text { LVL } 9948 \text { (cadastral value) x } 1.5 \% \text { (tax } \\
\text { rate) }=\text { LVL } 149.22\end{array}$ & 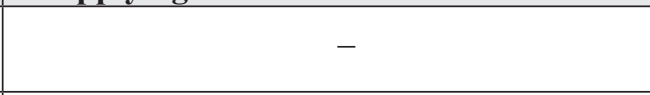 & $1.5 \%$ \\
\hline 2008 & $\begin{array}{l}\text { LVL } 67646 \text { (cadastral value) } \times 1 \%(\text { tax } \\
\text { rate) }=\text { LVL } 676.46\end{array}$ & $\begin{array}{l}\text { LVL } 149.22 \text { (tax amount in } 2007)+25 \% \\
\text { (limitation for the increase, } 25 \% \text { of LVL } \\
149.22)=\text { LVL } 186.53\end{array}$ & $0.3 \%$ \\
\hline 2009 & $\begin{array}{l}\text { LVL } 67646(\text { cadastral value }) \times 1 \%(\text { tax } \\
\text { rate })=\text { LVL } 676.46\end{array}$ & $\begin{array}{l}\text { LVL } 186.53 \text { (tax amount in } 2008)+25 \% \\
\text { (limitation for the increase, } 25 \% \text { of LVL } \\
186.53 \text { ) = LVL } 233.16\end{array}$ & $0.4 \%$ \\
\hline 2010 & $\begin{array}{l}\text { LVL } 62175 \text { (cadastral value) } \\
\text { X } 1.5 \%(\text { tax rate })=\text { LVL } 932.63\end{array}$ & $\begin{array}{l}\text { LVL } 233.16 \text { (tax amount in } 2009)+25 \% \\
\text { (limitation for the increase, } 25 \% \text { of LVL } \\
233.16)=\text { LVL } 291.45\end{array}$ & $0.5 \%$ \\
\hline 2011 & $\begin{array}{l}\text { LVL } 54714 \text { (cadastral value) } \times 1.5 \%(\text { tax } \\
\text { rate) }=\text { LVL } 820.71\end{array}$ & $\begin{array}{l}\text { LVL } 291.45 \text { (tax amount in } 2010)+25 \% \\
\text { (limitation for the increase, } 25 \% \text { of LVL } \\
291.45)=\text { LVL } 364.31\end{array}$ & $0.7 \%$ \\
\hline 2012 & $\begin{array}{l}\text { LVL } 49740 \text { (cadastral value) } \times 1.5 \%(\text { tax } \\
\text { rate) }=\text { LVL } 746.10\end{array}$ & $\begin{array}{l}\text { LVL 364.31(tax amount in 2011) }+25 \% \\
\text { (limitation for the increase, } 25 \% \text { of LVL } \\
364.31)=\text { LVL } 455.39\end{array}$ & $0.9 \%$ \\
\hline
\end{tabular}

Source: authors' construction based on data of the Immovable Property Tax Administration Program of Riga City Council

The sample shows that calculating the amount of immovable property tax by applying the limitation of the tax increase, the amount of tax is substantially reduced and the real tax rate ranges from $0.3 \%$ (in 2008) to $0.9 \%$ (in 2012). Therefore, the decision of the Latvian government to increase the immovable property tax rate to $1.5 \%$ of cadastral value (instead of the previous $1 \%$ ) in 2010 is incomprehensible. The rate is useless, if the limitation for the tax increase is retained, since the tax increases by $25 \%$ compared with the previous year. Similarly, taxpayers are confused in the situation when the cadastral value of immovable property decreases from 2010 but the amount of immovable property tax continues to increase.

The analysed sample allows concluding that it was more efficient to regulate tax burden in Latvia through tax rates (from 2010) - reducing immovable property tax rates and calculating the amount of immovable pro- 
perty tax pursuant to the cadastral values. It would facilitate work for tax administration and tax calculation would be more understandable for taxpayers. Thus, the basic principle for the imposition of taxes - simple administration - would be observed thanks to these changes and simultaneously ensuring the response to economic changes in the country consistent with the basic principle for the imposition of taxes (flexibility).

\subsection{Impact of tax structure on the amount of tax}

The administration of immovable property tax has revealed material shortcomings in the legal and regulatory enactments of Latvia regulating the registration of immovable property data in the Immovable Property State Cadastre Information System and the Land Register. Hence, persons having the joint ownership on immovable property, which includes both residential premises and premises used for economic activity but having only residential premises under the use, are forced to pay disproportionately large immovable property tax due to these shortcomings.

At present, Section 44 of the National Real Estate Cadastre Law does not prescribe registering the information on the procedure for use of immovable property, which is determined pursuant to the civil agreement of joint owners (Nekustamā īpašuma valsts kadastra likums, 2011). On the contrary, the procedure for use registered in the Land Register is not related with the structure of immovable property registered in the Cadastre Register - groups of premises, as it is not stipulated by the regulatory enactments. Hence, it is impossible to identify properly premises used by each joint owner (Zemesgrāmatu likums, 2011).

Therefore, municipalities presently have no access to the data necessary for the tax calculations to calculate taxes consistent with the procedure registered in the Land Register.

At present, different immovable property tax rates are determined in Latvia for residential buildings $(0.2-$ $0.6 \%)$ and buildings and their parts used for economic activity $(1.5 \%)$. Thereby, applying the mentioned rates of the regulatory enactments in cases when a building simultaneously has residential premises and premises used for economic activity leads to the situation when joint owners, who use only residential premises proportionally ideal units of property they have ownership rights on, are forced to pay tax for both the owned unit of residential premises and unit of premises used for economic activity for which, as already mentioned, owners have to pay an increased tax rate. The immovable property tax calculated in the aforementioned way is considerably higher for the joint owner who has ownership rights for use only to residential premises than in case the building is split into apartment properties consistent with the procedure stipulated by the law "On Apartment Property" when each owner has individual ownership rights on apartment property (Dzīvokḷa ipašuma likums, 2011).

To have an idea on the difference in the amount of immovable property tax, the authors will analyse a sample for the calculation of immovable property tax (Table 3 ) for an immovable property with the area of $1451 \mathrm{~m}^{2}$ located on Krišjānana Barona iela 28/28a in Riga. The property consists of one 6-storeyed building on Krišjāṇa Barona iela 28 and one 4-storeyed building on Krišjāṇa Barona iela 28a. Pursuant to the data of the Cadastre Register, a natural entity possesses $1 / 36$ undivided shares, while a legal entity possesses 2/36 dundivided shares of the immovable property with the area of $1451 \mathrm{~m}^{2}$ located on Krišjāna Barona iela 28/28A in Riga. However, pursuant to the procedure for use prescribed by the Land Register, the natural entity has in use an apartment in the 4-storeyed building on Krišjāņa Barona iela 28a, while the legal entity has in use shop premises in the 6-storeyed building on Krišjānna Barona iela 28. Considering the fact that two buildings are located on the analysed land area and the building has both residential and non-residential (used for economic activity) premises, the tax is calculated proportionally to the possessed undivided shares of residential and non-residential premises. The calculation of immovable property tax ignores really possessed residential or non-residential area. According to the data of Table 3, the amount of immovable property tax for the owner possessing the apartment in this case equals LVL 145.44, while for the owner possessing shop premises LVL 290.88. Yet, if the immovable property tax is calculated consistent with the procedure for use registered 
in the Land Register, the amount of immovable property tax for the owner possessing the apartment would be only LVL 37.87 , which is LVL 107.57 or $65.8 \%$ less. In contrast, the owner possessing shop premises should pay LVL 568.04, which is LVL 277.16 or $48.8 \%$ more.

Table 3. The calculation of immovable property tax consistent with the data registered in the Cadastre Register and the procedure for use registered in the Land Register

\begin{tabular}{|c|c|c|c|c|}
\hline \multirow[t]{2}{*}{ Taxable item } & \multicolumn{2}{|c|}{$\begin{array}{c}\text { Tax calculation consistent } \\
\text { with the data registered in the } \\
\text { Cadastre Register }\end{array}$} & \multicolumn{2}{|c|}{$\begin{array}{l}\text { Tax calculation consistent } \\
\text { with the procedure for } \\
\text { use registered in the Land } \\
\text { Register }\end{array}$} \\
\hline & $\begin{array}{c}\text { Owner } \\
\text { possesses an } \\
\text { apartment }\end{array}$ & $\begin{array}{c}\text { Owner } \\
\text { possesses } \\
\text { shop premises }\end{array}$ & $\begin{array}{c}\text { Owner } \\
\text { possesses an } \\
\text { apartment }\end{array}$ & \begin{tabular}{|c|} 
Owner \\
possesses shop \\
premises
\end{tabular} \\
\hline $\begin{array}{l}\text { Building on Krišjāṇa Barona iela } 28 \text { (6-storeys) } \\
\text { Residential area (tax rate } 0.2 \% \text { ) } \\
\text { Non-residential area (tax rate } 1.5 \% \text { ) }\end{array}$ & \begin{tabular}{|l} 
LVL 6.69 \\
LVL 30.45 \\
\end{tabular} & \begin{tabular}{|l} 
LVL 13.38 \\
LVL 60.9 \\
\end{tabular} & - & $\begin{array}{l}- \\
\text { LVL } 568.04\end{array}$ \\
\hline $\begin{array}{l}\text { Building on Krišjāṇa Barona iela 28a (4-storeys) } \\
\text { Residential area (tax rate } 0.2 \% \text { ) } \\
\text { Non-residential area (tax rate } 1.5 \% \text { ) }\end{array}$ & $\begin{array}{l}\text { LVL } 14.63 \\
\text { LVL } 93.67 \\
\end{array}$ & $\begin{array}{l}\text { LVL } 29.26 \\
\text { LVL } 187.34\end{array}$ & $\begin{array}{l}\text { LVL } 37.87 \\
-\end{array}$ & $\begin{array}{l}- \\
- \\
-\end{array}$ \\
\hline $\begin{array}{ll}\text { TOTAL } \\
\end{array}$ & Ls 145.44 & Ls 290.88 & Ls 37.87 & Ls 568.04 \\
\hline
\end{tabular}

Source: authors' construction based on data of the Immovable Property Tax Administration Program of Riga City Council

This allows concluding that the basic principle for tax imposition - uniformity and justice - is materially violated when calculating immovable property tax consistent with the possessed undivided shares (proportionally to behoving residential and non-residential premises) and ignoring the actual procedure for use of immovable property. For taxpayers who actually use only residential premises, the immovable property tax is calculated proportionally also to the undivided share behooving to non-residential premises, thus, significantly increasing the amount of immovable property tax (tax rate $1.5 \%$ ). In contrast, for taxpayers who actually use only non-residential premises, the amount of immovable property tax is considerably reduced, since the tax is calculated proportionally also to the undivided share behooving to residential premises (tax rate $0.2-0.6 \%$ ).

It shall be noted that there are many such properties in Latvia, especially in Riga. Predominantly such joint properties are established in cases when a house owner has not actually separated his/her denationalised property but s/he has expropriated its undivided shares through the agreement of the procedure for use, thus, avoiding additional expenses necessary for separation of property into apartments. At present, many developers of new projects continue to follow this practice, thus, causing the mentioned problems for purchasers of undivided property shares in the future.

The solution might be the recommendation to separate immovable property into apartment properties, which is the competence of owners themselves. However, most frequently the properties are not being separated due to the fact that property separation expenses shall be covered by the owners themselves and difficulties of joint owners to agree upon the separation of the joint property into apartments properties.

To solve this problem on the state level, state and municipal institutions should be invited to start a discussion on the possible solutions and legal regulation with the aim to ensure municipalities with the necessary data allowing to apply the most fair procedure for tax calculation, i.e. to calculate tax consistent with the procedure for use registered in the Land Register. Certainly, it shall be taken into account that state and municipal institutions should perform a voluminous preparation work to ensure the appropriate registers with the necessary data and to modify software. This means that the procedure for property use registered in the Land Register shall be appropriately registered also in the Cadastre Register, from which the data on the pro- 
perty composition are used for the tax calculation. Therefore, one should take account of material additional resources and required time for the implementation of the possible changes. However, these difficulties may not be justified by the system when unfair and incomprehensible to taxpayers procedure for the calculation of immovable property tax should be maintained in Latvia due to non-existent mutual tieback between two institutions and information systems subjected to one ministry.

\subsection{Impact of the cadastral value on the tax amount}

In Latvia, the cadastral value is the base for immovable property tax. The cadastral value is the value of land and constructions, which is calculated consistent with internationally recognised, unified, and state approved criteria in the entire country, considering the place of property location, registered data on qualitative condition of property, type of use, encumbrances, and other criteria. Formulae for calculating the cadastral value are made so that the cadastral value of every property would be to the utmost close to its market value without an individual evaluation of each property (Viss par kadastrālo vērtību, 2012).

Considering that the cadastral value is the base for immovable property tax leading to the tax calculation, it is very essentially to review ways how the State Land Service determines the cadastral values of properties, since it is impossible to establish a fair tax system without adequate and inter-comparable cadastral values. Cadastral valuation may not be based only on real estate market information on the cases of expropriation, as they are affected by many additional factors - investment of cash of unknown origin, availability of loans, speculative transactions etc. (Štucere, 2010:136). The present determination of cadastral value mainly applying the market price of individual sold objects in a region leads to the situation that the amount of cadastral value considerably increases in individual regions (Jūrmala), while it decreases in other regions. The practice of some highly developed countries to use the price of market transactions for the determination of cadastral value is not applicable in Latvia. This method is suited for closed economies, basically, in large countries, which have established stable society and real estate purchasers are mainly the state residents.

Nevertheless, land lease or revenues gained from the use of immovable property are the classically recognised source of immovable property tax, the cadastral value in Latvia is never related with these revenues. Therefore, the value of immovable property in the future shall be determined by analysing revenues that might be gained from the lease of immovable property. This method for the determination of cadastral value would be fairer and it would characterise the real value of immovable property. At present, the property value depends on the place of location and the number of transactions in particular territory, thus, causing an artificial increase of cadastral value in the regions experiencing high demand for properties (Jūrmala, Mežaparks).

The system of cadastral valuation should be revised in the future: land should be evaluated by expropriation and not lease transactions. The method of capitalisation might be applied for the cadastral evaluation of land. It analyses and determines the income, which the owner may gain from property lease or rent within a year. This approach is widespread in the Western countries (Sweden, Denmark), since these countries have strictly determined procedure for accounting of lease income (Štucere, 2010: 136).

Latvia should address an issue on the establishment of mechanism for accrual of immovable property lease data. A single register could be one of the possibilities; the register could contain information on lease transactions performed by natural and legal entities. The cadastral value of buildings should be derived from the renovation costs and not the cadastral value of land. The method of costs could be applied for the cadastral evaluation of buildings simultaneously calculating the construction costs of buildings. At present, the Construction Information System is under the process of development in Latvia and it is envisaged to include information on construction costs into this system (Štucere, 2010: 136).

Latvia should also address the issue of impact of physical condition and age of buildings on the cadastral value, since very many concrete examples show a considerable mutual discrepancy among cadastral values, 
i.e. adjacent buildings have similar cadastral values irrespective of the age and physical depreciation of buildings.

Samples summarised in Table 4 outline that 5 -storeyed residential buildings located in one zone differ by the years of construction and physical depreciation. However, cadastral values of one bedroom apartments located in these buildings and hence, the amount of immovable property tax differ only slightly. For example, the cadastral value of one bedroom apartment located in the building (built in 1962) on Brīvības gatve 367 in Riga is LVL 9734. Though, the cadastral value of one bedroom apartment located in the building (built in 2006) on Brīvỉbas gatve 386 in Riga is LVL 12392, which is only LVL 2658 or 27 \% more. The cadastral value for apartments is determined irrespective of the fact that the State Land Service has fixed a depreciation of $35 \%$ for the building constructed in 1962 and the building on Brīvības gatve 367 is built 44 years earlier than the building on Brivinibas gatve 386. Yet, it should be mentioned that multi-storeyed buildings constructed earlier were inspected at the time when buildings were privatised and inventory or cadastral survey of apartments was done. The table shows that the building on Brīvības iela 386 in Riga is inspected in 2000. The inspection of physical condition of buildings shall be required by an owner and the owner has to pay the inspection price stated by the State Land Service. At present, the government of Latvia has not envisaged to cover expenses of mass inspection of buildings and updating of data.

Table 4. The comparison of cadastral value and amount of immovable property tax for residential buildings in 2012

\begin{tabular}{|l|l|l|l|l|l|}
\hline \multicolumn{1}{|c|}{ Address of building } & \multicolumn{1}{|c|}{$\begin{array}{c}\text { Year of } \\
\text { construction }\end{array}$} & $\begin{array}{c}\text { Latest } \\
\text { inspection of } \\
\text { building }\end{array}$ & $\begin{array}{c}\text { Cadastral value } \\
\text { of one bedroom } \\
\text { apartment, LVL }\end{array}$ & $\begin{array}{c}\text { Amount of } \\
\text { immovable } \\
\text { property tax, } \\
\text { LVL }\end{array}$ & $\begin{array}{c}\text { Depreciation } \\
\text { of building }\end{array}$ \\
\hline Brīvības gatve 386, Riga & 2006 & 2006 & 12392 & 24.78 & - \\
\hline Brīvības gatve 367, Riga & 1962 & 2000 & 9734 & 19.47 & $35 \%$ \\
\hline
\end{tabular}

Source: authors' construction based on data of the Immovable Property

Tax Administration Program of Riga City Council

The analysis of the calculated immovable property tax in 2012 (Table 4) outlines that the amount of immovable property tax (LVL 24.78) for one bedroom apartment in the building located on Brīvìbas gatve 386 is only LVL Ls 5.31 more than the amount of immovable property tax (LVL 19.47) for one bedroom apartment in the building located on Brīvības gatve 367. The analysed sample allows concluding that it is almost impossible to ensure a fair tax calculation applying such cadastral values for the calculation of immovable property tax. Therefore, the process for determination of cadastral value in Latvia needs changes, as tax determination should be based on the principles of legal confidence and commensurability.

In addition, the procedure for revaluation of immovable property and forecasting of changes in cadastral values on the beginning of the taxation period should be revised in Latvia. At present, there is a problem that the annual changes of the base of cadastral value force a payer of immovable property tax to consider also annual changes in cadastral values and taxes, thus, hindering planning of expenses in the medium term and causing a tension in the society. Similarly, the regulatory enactments do not prescribe the time and the society has no knowledge on the time when the cadastral values should correspond to the market situation; thus, allowing the way for interpretation on the compliance in different periods - on the moment of approval, or the beginning or end of the taxation period. On the conditions of downward market, the regulatory enactments prescribe to determine the base indicators of values on the moment when the base of values becomes efficient (to evaluate the price drop forecast one year ahead). Unfortunately, forecasts done one year ahead not always allow precise evaluation, thus, causing necessity to make corrections in the following year and causing dissatisfaction and incomprehension of the society, especially in case of increasing cadastral values. Here, the possible solution could be mass revaluation once in two years if the data describing the item have not changed and determining a fixed reporting date for the base of cadastral values (concrete situation on 
the real estate market) without forecasting of the real estate market on the beginning of the taxation period. Simultaneously, the necessity for forecasting in cases of extremely radical decline in the values of real estate market should be envisaged in Latvia. Therefore, the State Land Service would have the possibility to prepare a qualitative and extended report on the changes in the base of cadastral values and payers of immovable property tax will have certain stability in planning of tax payments.

\section{Conclusions}

1. The tax system of Latvia may be described as unstable due to its frequent and considerable changes and expressed direction towards employment taxes (52.9\% of the total tax revenues in 2011). The immovable property tax is included into capital taxes and its share equalled $2.8 \%$ of total tax revenues in 2011 .

2. Lately, the set of items taxable with immovable property tax has been expanded in Latvia - taxation of residential buildings with immovable property tax has been started from 2010 and tax rates have been increased from 2011, thus, the largest immovable property tax revenues amounting to LVL 110.2 million were collected in Latvia. It is envisaged to ensure the rights to local governments to determine the immovable property tax rates from 2013 within the range of $0.2 \%-3 \%$ set by the central government.

3. Since the real estate market activities and prices have rapidly declined from 2010 considerably affecting the cadastral values of properties, it would be more efficient to cancel the limitation set by the state for the tax increase and regulate tax burden through tax rates. It would facilitate work for tax administration and tax calculation would be more understandable to taxpayers.

4. The state and municipal institutions should be invited to start a discussion on the possible solutions and legal regulation with the aim to ensure municipalities with the necessary data allowing to apply the most fair procedure for tax calculation, i.e. to calculate tax consistent with the procedure for use registered in the Land Register. It should be done on the state level.

5. The system of cadastral valuation should be revised in Latvia: land should be evaluated by expropriation and not lease transactions. The method of costs could be applied for the cadastral evaluation of buildings simultaneously calculating the construction costs of buildings. The issue of mass inspection of buildings and updating of data should be addressed in Latvia.

6. Mass revaluation of the cadastral value should be ensured in Latvia once in two years if the data describing the item have not changed and determining a fixed reporting date for the base of cadastral values. Therefore, the State Land Service would have the possibility to prepare a qualitative and extended report on the changes in the base of cadastral values and payers of immovable property tax will have certain stability in planning of tax payments.

\section{References}

Dzīvoklı īpašuma likums (Law on Apartment Property): LR likums. (2011). Available at: http://www.likumi.lv/doc. php?id=221382.

Fridriksone, M. (2009). Kadastrālās vērtības ir ievērojami kritušās (Cadastral Values have Considerably Decreased). Dienas bizness, Saldo Nr. 13, gada augusts, p. 4-8.

Ketners, K., Titova, S. (2009). Nodoklu politika Eiropas Savienības vidē (Tax Policy in the European Union Environment). Banku augstskola, Biznesa un finanšu pētniecības centrs, p. 127.

Kopsavilkums par budžeta ieņēmumu daḷas izpildi 2011.gada 12 mēnešos (Summary on the Performance of Budget Revenues in 2011). Available at: http://www.vid.gov.lv/dokumenti/noderigi/statistika/nodoklu\%20ienemumi/kopsavilkums_ien_2011g.pdf.

Kopsavilkums par budžeta ieñēmumu daḷas izpildi 2010.gada 12 mēnešos (Summary on the Performance of Budget Revenues in 12 Months of 2010). Available at: http://www.vid.gov.lv/dokumenti/noderigi/statistika/nodoklu\%20 ienemumi/ien_12_2010.pdf.

Likuma „Par nekustamā ìpašuma nodokli” normu piemērošanas kārtība (Procedure for Applications of Norms Stipulated by the Law on Immovable Property Tax), MK noteikumi Nr.495. (2011). Available at: http://www.likumi.lv/ doc.php?id=138366. 
Likumprojekta „Grozījumi likumā „Par nekustamā īpašuma nodokli” sākotnējās ietekmes novērtējuma ziṇojums (Report on Initial Impact Assessment of the draft Law “Amendments to the Law on Immovable Property Tax”). (2012). Available at: www.mk.gov.lv/doc/2005/FManot_150312_NIN_2013.303.doc.

Makroekonomikas un budžeta apskats (Survey on Macroeconomics and Budget). (2011). LR Finanšu ministrija. Available at: http://fm.gov.lv/files/files/4C05BC220873001328083638827981.pdf.

Nekustamā ìpašuma valsts kadastra likums (Law on Immovable Property State Cadastre): LR likums. (2011). Available at: http://www.likumi.lv/doc.php?id=124247.

Par nekustamā īpašuma nodokli (On Immovable Property Tax): LR likums. (2011). Available at: http://www.likumi. lv/doc.php?id=43913.

Par tautsaimniecības attīstību un kopbudžeta izpildes gaitu (On Progress of Economic Development and Performance of Consolidated Budget). (2007). LR Finanšu ministrija. Available at: http://www.fm.gov.lv/files/files/2007_IV.pdf.

Rīgas domes Nekustamā ìpašuma nodokļa administrēšanas sistēmas dati (Data of the Immovable Property Tax Administration System of Riga City Council).

Štucere, S. (2010). Samērīga nekustamā īpašuma nodokḷa piemērošanas problēmas Latvijā (Problems for Application of Commensurate Immovable Property Tax in Latvia). RTU Zinātniskie raksti. Ekonomika un uzņēmējdarbība, Sērija 3, Sējums 20, p. 133-139.

Viss par kadastrālo vērtību (Everything on Cadastral Value). (2012). Valsts Zemes dienests. Available at: http://kadastralavertiba.lv/vienkarsi-par-kadastralo-vertibu/.

Zemesgrämatu likums (Law on Land Register): LR likums. (2011). Available at: http://www.likumi.lv/doc.php?id=60460.

\section{LATVIJOS NEKILNOJAMOJO TURO MOKESČIŲ DYDŽIUI ITAKOS TURINČIUU VEIKSNIŲ VERTINIMAS}

Sandra Stucere, Gunita Mazure

Latvijos žemės ūkio universitetas (Latvija)

\section{Santrauka}

Šiuo tyrimu siekta išanalizuoti Latvijos nekilnojamojo turto mokesčio ypatumus ir įvertinti veiksnius, kurie daro įtaką jų dydžiui, pagrindinius mokesčių skyrimo principus. Svarbu aptarti metodus, kuriais remdamasi Valstybinė žemès tarnyba nustato kadastrinę nekilnojamojo turto vertę, kuri yra nekilnojamojo turto mokesčio apskaičiavimo pagrindas. Būtina revizija, nes neịmanoma be tinkamų ir palyginamų kadastrinių verčių sukurti sąžiningos mokesčių sistemos.

Ateityje žemė bus vertinama remiantis nuomos, o ne pirkimo sandoriais Latvijoje, tuo tarpu statinių kadastrinè vertė gali būti nustatoma panašiais metodais, kuriais nustatomos statinių statybos sąnaudos. Latvijoje būtina masinè statinių fizinès būklès inspekcija ir duomenų atnaujinimas. Valstybiniu lygmeniu siekiama nustatyti sąžiningą mokesčiu skaičiavimo procedūrą (mokesčiai skaičiuojami remiantis nekilnojamojo turto panaudojimo procedūra Žemès registre), panaikinti vietinių savivaldybių nustatytus apribojimus nekilnojamojo turto mokesčio didèjimui, reguliuoti mokesčių naštą keičiant jų dydi.

PAGRINDINIAI ŽODŽIAI: nekilnojamojo turto mokestis, mokesčio didèjimui ribojimai, nuosavybès struktūra, kadastriné verté.

JEL KLASIFIKACIJA: H29 